\title{
KEBIJAKAN PERTANAHAN DALAM UNDANG-UNDANG NOMOR 25 TAHUN 2007 TENTANG PENANAMAN MODAL
}

\author{
Arie S. Hutagalung ${ }^{1}$
}

\begin{abstract}
Abstrak
The author presents the current issue on Indonesia land policy situation and the impacts of the new investment law under law number 25 year 2004. The main problems are on the controversy (disharmony) through the investment law perspectives on the land right duration that then has been decided by Constitutional Court of the Republic Indonesia) as constitutional violations. Then the method of land right to be granted had been revised under the constitution court decision and deemed the stipulation in article 22 of investment law have no legal binding and regarded have no effective power. This is reflection on more picture of developing country in law policy which mostly embarks on situational need and/or by foreign pressures that then easily disobey another specific norm in current effective law. This article bares how disharmony was happened between investment law to agaraian law in Indonesia.
\end{abstract}

Kata kunci: hukum pertanahan, kebijakan, penanaman modal

\section{Pengantar}

Kegiatan penanaman modal merupakan salah satu kegiatan ekonomi yang mendatangkan penghasilan bagi negara Indonesia. Dari waktu ke waktu Pemerintah terus berusaha menyempurnakan peraturan-peraturan di bidang penanaman modal demi kemudahan dan kelancaran kegiatan tersebut. Salah satu hal yang paling vital dalam peraturan tersebut adalah mengenai fasilitas yang diberikan Pemerintah kepada pihak yang melakukan penanaman modal di Indonesia karena hal inilah yang membuat para pihak penanam modal tertarik untuk melakukan penanaman modal. Salah satu fasilitas yang paling vital untuk diperhatikan adalah mengenai pemberian penggunaaan tanah untuk penanaman modal karena tanah merupakan faktor modal utama dan juga aset yang pasti dibutuhkan oleh pelaku penanaman modal. Oleh karena itu pengaturan mengenai kebijakan pertanahan dalam penanaman modal merupakan hal yang amat dinantikan oleh berbagai pihak. Pemerintah harus

\footnotetext{
${ }^{1}$ Guru Besar Hukum Agraria Fakultas Hukum Universitas Indonesia.
} 
berhati-hati dalam membuat kebijakan tersebut karena di satu sisi, Pemerintah harus membuat kebijakan yang dapat menarik pihak penanam modal untuk menanamkan modalnya di Indonesia dan di sisi lain kebijakan tersebut tidak boleh bertentangan dengan ketentuan peraturan perundangundangan yang telah ada dan tidak bertentangan dengan rasa keadilan masyarakat Indonesia.

Hukum Tanah Nasional yang pokok-pokoknya tercantum dalam Undang-Undang No. 5 Tahun 1960 tentang Peraturan Dasar Pokok-Pokok Agraria (UUPA) merupakan pelaksanaan langsung dari Pasal 33 ayat 3 Undang-Undang Dasar 1945, sekaligus juga merupakan pengejawantahan aspirasi bangsa Indonesia dalam pembaharuan Hukum Tanah Nasional. ${ }^{2}$ Dalam UUPA dikenal berbagai macam jenis Hak Atas Tanah diantaranya yaitu Hak Guna Usaha, Hak Guna Bangunan dan Hak Pakai yang mempunyai subyek dan peruntukkan yang berbeda untuk setiap jenisnya. Dalam Undang-Undang No. 25 Tahun 2007 tentang Penanaman Modal (UUPM) diatur mengenai kemudahan pelayanan pemberian izin penggunaan hak-hak atas tanah tersebut, namun pengaturan ini kemudian diajukan uji material dengan pertimbangan bertentangan dengan Pasal 33 UndangUndang Dasar 1945. ${ }^{3}$

\section{Permasalahan}

1. Apakah Undang-Undang Penanaman Modal mengubah jangka waktu dan lembaga pertanahan yang terdapat dalam UUPA?

2. Bagaimanakah status kebijakan pertanahan dalam UUPM setelah diubah oleh Mahkamah Konstitusi?

\section{Konsep Hukum Tanah Nasional Yang Berkaitan Dengan Undang- Undang Penanaman Modal}

Hak atas tanah dalam hukum tanah nasional pada dasarnya meliputi sebagai berikut: ${ }^{4}$

2 Arie S. Hutagalung (a), "Tebaran Pemikiran Seputar Masalah Hukum Tanah", (Jakarta: Penerbit Lembaga Pemberdayaan Hukum Indonesia, 2005), hal. 151.

3 (CRP/Ycb), "Judicial Review: UUPM vs. Tanah Untuk Rakyat", <http://www.hukumonline.com/detail.asp?id=17301\&cl=Berita>, 3 Agustus 2007. 
1. Hak-hak atas tanah yang primer yaitu hak-hak atas tanah yang diberikan oleh negara dan bersumber langsung pada hak bangsa indonesia atas tanah. Jenis hak atas tanahnya antara lain: hak milik, hak guna usaha, hak guna bangunan dan hak pakai.

2. Hak-hak atas tanah yang sekunder, yaitu hak-hak atas tanah yang diberikan oleh pemilik tanah dan bersumber secara tidak langsung pada hak bangsa indonesia atas tanah.

Hak atas tanah yang sekunder disebut pula hak baru yang diberikan di atas tanah hak milik dan selalu diperjanjikan antara pemilik tanah dan pemgegang hak baru dan akan berlangsung selama jangka waktu tertentu. Jenis hak atas tanah yang sekunder antara lain: hak guna bangunan, hak pakai, hak sewa, hak usaha bagi hasil, hak gadai atas tanah, hak menumpang. ${ }^{5}$

Menurut ketentuan Hukum Tanah Nasional, perusahaan yang berstatus badan hukum Indonesia termasuk PT PMA (Penanaman Modal Asing) dapat menguasai tanah sesuai dengan peruntukannya dengan hak-hak sebagai berikut: $^{6}$

1. Hak Guna Bangunan (HGB) untuk perumahan, industri, dan lainlain dalam rangka fungsi tanah sebagai wadah

2. Hak Guna Usaha (HGU) untuk pertanian, perikanan, perkebunan dan peternakan

3. Hak Pakai (HP) untuk keperluan pertanian maupun non-pertanian.

4. Hak Pengelolaan (HPL) khusus untuk Badan Usaha Milik Negara (BUMN) yang $100 \%$ sahamnya dimiliki negara yang penguasaan tanahnya tidak terbatas pada penggunaan untuk keperluan sendiri akan tetapi dimaksudkan untuk menyerahkan bangunan dan tanah kepada pihak ketiga menurut persyaratan yang ditentukan oleh perusahaan pemegang HPL, meliputi segi-segi penggunaan, jangka waktu dan keuangan.

Dari hak-hak yang disebutkan diatas, hak atas tanah yang penting untuk diketahui untuk pelaku penanaman modal dan diatur dalam UUPM adalah HGU, HGB dan HP.

${ }^{4}$ Arie Sukanti Hutagalung dan Markus Gunawan (b), "Kewenangan Pemerintah di Bidang Pertanahan", (Jakarta: Raja Grafindo Persada, 2008.), hal. 29.

${ }^{5}$ Ibid., hal. 30 .

${ }^{6}$ Arie S. Hutagalung (a), Op. Cit., hal. 225. 


\section{A. Hak Guna Usaha}

Menurut Pasal 28 UUPA, HGU adalah hak yang khusus untuk mengusahakan tanah yang bukan miliknya sendiri guna perusahaan pertanian, perikanan, dan peternakan dengan luas paling sedikit 5 hektar serta hak ini pun dapat beralih kepada pihak lain dan dapat dibebani dengan Hak Tanggungan. ${ }^{?}$

Pasal 29 UUPA menyatakan hal-hal mengenai hak guna usaha sebagai berikut:

(1) HGU diberikan untuk waktu paling lama 25 tahun;

(2) Untuk perusahaan yang memerlukan waktu yang lebih lama dapat diberikan HGU untuk waktu paling lama 35 tahun;

(3) Atas permintaan pemegang hak dan mengingat keadaan perusahaannya jangka waktu yang dimaksud dalam ayat 1 dan ayat 2 pasal ini dapat diperpanjang dengan waktu paling lama 25 tahun.

Menurut Pasal 30 UUPA yang dapat mempunyai HGU ialah:

a. Warga negara Indonesia;

b. Badan hukum yang didirikan menurut hukum Indonesia dan berkedudukan di Indonesia.

Sedangkan pengaturan mengenai HGU dalam Peraturan Pemerintah Nomor 40 Tahun 1996 (PP 40/1996) dalam Pasal 8 adalah sebagai berikut:

(1) HGU sebagaimana dimaksud dalam Pasal 6 diberikan untuk jangka waktu paling lama tiga puluh lima tahun dan dapat diperpanjang untuk jangka waktu paling lama dua puluh lima tahun;

(2) Sesudah jangka waktu HGU dan perpanjangannya sebagaimana dimaksud dalam ayat (1) berakhir, kepada pemegang hak dapat diberikan pembaharuan HGU di atas tanah yang sama; ${ }^{8}$

Untuk kepentingan penanaman modal, permintaan perpanjangan atau pembaharuan $\mathrm{HGU}$ dapat dilakukan sekaligus dengan membayar uang pemasukan yang ditentukan untuk itu pada saat pertama kali mengajukan permohonan HGU. ${ }^{9}$

\footnotetext{
${ }^{7}$ Arie Sukanti Hutagalung dan Markus Gunawan (b), Op. Cit. hal. 33.

${ }^{8}$ Bandingkan dengan Pasal 29 UUPA
} 


\section{B. Hak Guna Bangunan}

HGB tidak mengenai tanah pertanian oleh karena itu selain atas tanah yang dikuasai langsung oleh negara, dapat pula diberikan atas tanah Hak Milik seseorang. ${ }^{10}$ Ketentuan mengenai HGB tersebut diatur dalam Pasal 35 UUPA yang berbunyi sebagai berikut:

(1) Hak Guna Bangunan adalah hak untuk mendirikan dan mempunyai bangunan-bangunan atas tanah yang bukan miliknya sendiri, dengan jangka waktu paling lama 30 tahun.

(2) Atas permintaan pemegang hak dan dengan mengingat keperluan serta keadaan bangunanbangunannya, jangka waktu tersebut dalam ayat 1 dapat diperpanjang dengan waktu paling lama 20 tahun.

(3) Hak Guna Bangunan dapat beralih dan dialihkan kepada pihak lain

Sedangkan mengenai subjek dari HGB, berdasarkan Pasal 36 UUPA adalah:

a. Warganegara Indonesia;

b. Badan hukum yang didirikan menurut hukum Indonesia dan berkedudukan di Indonesia.

Dalam Pasal 25 ayat (1) PP 40/1996 dinyatakan bahwa HGB dapat diberikan untuk jangka waktu paling lama tiga puluh tahun dan dapat diperpanjang untuk jangka waktu paling lama dua puluh tahun. Menurut Pasal 25 ayat (2) PP 40/1996 tersebut dinyatakan sesudah jangka waktu tersebut dan perpanjangannya berakhir maka dapat diberikan pembaharuan HGB yang sama kepada bekas pemegang hak milik. Untuk HGB di atas tanah Negara apabila dimohonkan untuk diperpanjang atau diperbaharui harus memenuhi syarat Pasal 26 ayat 1 PP 40/1996 yaitu:

a. Tanahnya masih dipergunakan dengan baik sesuai dengan keadaan, sifat dan tujuan pemberian hak tersebut;

9 Indonesia (a), Peraturan Pemerintah Tentang Hak Guna Usaha, Hak Guna Bangunan Dan Hak Pakai Atas Tanah, PP No. 40, LN N0. 58 Tahun 1996, TLN No. 3643 ,Pasal 11 ayat 1 .

${ }^{10}$ Arie Sukanti Hutagalung dan Markus Gunawan (b), Op. Cit. hal. 36. 
b. Syarat-syarat pemberian hak tersebut dipenuhi oleh pemegang hak

c. Pemegang hak masih memenuhi syarat sebagai pemegak hak sebagaimana disebutkan dalam pasal 19;

d. Tanah tersebut masih sesuai dengan Rencana Tata Ruang Wilayah yang bersangkutan.

HGB diatas tanah HPL dapat diperpanjang atau diperbaharui atas permohonan pemegang $\mathrm{HGB}$ setelah mendapat persetujuan dari pemegang HPL. ${ }^{11}$ Bahkan untuk kepentingan penanaman modal, dapat dimohonkan perpanjangan dan pembaharuan HGB secara sekaligus dengan membayar uang pemasukan yang ditentukan untuk itu pada saat pertama kali mengajukan permohonan $\mathrm{HGB} .{ }^{12}$

\section{Hak Pakai}

Menurut Pasal 41 UUPA HP adalah hak untuk menggunakan dan/atau memungut hasil dari tanah yang dikuasai langsung oleh negara atau tanah milik orang lain yang mana penggunaannya untuk keperluan pertanian dan non pertanian (hunian, perkantoran) dengan memperhatikan aspek Rencana Umum Tata Ruang Daerah (RUTRD) setempat. ${ }^{13}$ Menurut Pasal 41 ayat (2) UUPA, HP dapat diberikan:

a. selama jangka waktu yang tertentu atau selama tanahnya dipergunakan untuk keperluan yang tertentu;

b. dengan cuma-cuma, dengan pembayaran atau pemberian jasa berupa apapun.

Menurut Pasal 42 UUPA, subjek yang dapat mempunyai HP adalah:

a. Warganegara Indonesia;

b. Orang asing yang berkedudukan di Indonesia;

c. Badan hukum yang didirikan menurut hukum Indonesia dan berkedudukan di Indonesia;

${ }^{11}$ Indonesia (a), Op. Cit., Pasal 26 ayat (2).

${ }^{12}$ Ibid., Pasal 28 ayat (1).

${ }^{13}$ Arie S Hutagalung (a), Op. Cit., hal. 101.

Catatan: Pada saat ini istilah RUTRD telah diubah menjadi Rencana Umum Tata Ruang Wilayah (RUTRW). 
d. Badan hukum asing yang mempunyai perwakilan di Indonesia.

Dalam Pasal 45 PP 40/1996 dinyatakan jangka waktu pemberian dan perpanjangan HP dalam yang berbunyi:

(1) Hak Pakai sebagaimana dimaksud dalam pasal 42 diberikan untuk jangka waktu paling lama dua puluh lima tahun dan dapat diperpanjang untuk jangka waktu paling lama dua puluh tahun atau diberikan untuk jangka waktu yang tidak ditentukan selama tanahnya dipergunakan untuk keperluan tertentu

(2) Sesudah jangka waktu Hak Pakai atau perpanjangannya sebagaimana dimaksud dalam ayat (1) habis, kepada pemegang hak dapat diberikan pembaharuan Hak Pakai atas tanah yang sama

(3) Hak Pakai yang diberikan untuk jangka waktu yang tidak ditentukan selama dipergunakan untuk keperluan tertentu sebagaimana dimaksud dalam ayat (1) diberikan kepada:

(a) Departemen, Lembaga Pemerintahan NonDepartemen, dan Pemerintah Daerah;

(b) Perwakilan Negara Asing dan Perwakilan Badan Internasional;

(c) Badan Keagamaan dan Badan Sosial.

Pada Pasal 46 ayat 2 PP 40/1996 dinyatakan bahwa HP atas tanah HPL dapat diperpanjang atau diperbaharui atas usul pemegang HP. Selain itu Pasal 48 ayat 1 PP 40/1996 menyatakan untuk kepentingan penanaman modal, permintaan perpanjangan dan pembaharuan HP dapat dilakukan sekaligus dengan pembayaran uang pemasukan yang ditentukan untuk itu pada saat pertama kali mengajukan permohonan HP. HP atas tanah Hak Milik dapat diberikan oleh Pemegang Hak Milik dengan suatu Akta Pemberian Hak dihadapan Pejabat Pembuat Akta Tanah (PPAT) (Pasal 49 PP 40/1996)

Apabila disimpulkan maka Hak-Hak atas Tanah yang terdiri dari HGU, HGB, dan HP setelah diperpanjang dan setelah pembaharuan hak adalah sebagai berikut: 
1. Jangka waktu pemberian HGU ditetapkan selama 35 tahun dan dapat diperpanjang selama 25 tahun serta dapat dimohonkan pembaharuan selama 35 tahun;

Apabila diakumulasikan yaitu $35+25+35$ maka jumlah keseluruhannya sama dengan 95 tahun;

2. Jangka waktu pemberian HGB diberikan untuk waktu paling lama 30 tahun dan dapat diperpanjang selama 20 tahun serta dapat dimohonkan pembaharuan hak untuk jangka waktu paling lama 30 tahun;

Apabila diakumulasikan yaitu $30+20+30$ maka jumlah keseluruhannya sama dengan 80 tahun.

3. Jangka waktu pemberian HP ditetapkan selama 25 tahun dan dapat diperpanjang selama 20 tahun serta dapat diperbaharui selama 25 tahun.

Apabila diakumulasikan yaitu $25+20+25$ maka jumlah keseluruhannya sama dengan 70 tahun. ${ }^{14}$

\section{Ketentuan Mengenai Kebijakan Pertanahan Dalam Undang- Undang No. 25 Tahun 2007 tentang Penanaman Modal (UUPM)}

UUPM lahir ketika suasana investasi di Indonesia sedang lesu. Melalui Undang-Undang ini, Pemerintah mencoba memikat para investor terutama investor asing untuk menanamkan modal di Indonesia. Dalam UndangUndang ini Pemerintah mulai membuka bidang-bidang usaha yang terlarang untuk investasi asing yang terdapat dalam ketentuan peraturan perundangundangan yang lama (UU Penanaman Modal Asing dan UU Penanaman Modal Dalam Negeri) dan mulai memberikan perlakuan yang sama terhadap penanam modal asing dengan penanam modal dalam negeri.

Pada pasal 18 ayat (1) UUPM dinyatakan bahwa Pemerintah memberikan fasilitas kepada penanam modal yang melakukan penanaman modal seperti yang terdapat dalam Pasal 18 ayat (4) UUPM yang salah satunya berupa keringan pajak bumi dan bangunan untuk bidang usaha tertentu pada kawasan atau wilayah tertentu. ${ }^{15}$ Pada Pasal 21 UUPM

${ }^{14}$ Ibid., Hak Pakai dapat berjangka waktu maksimal 70 tahun khusus bagi keperluan penanaman modal asing. Dari aspek bisnis dan investasi jangka waktu tersebut amat mendukung kegiatan bisnis dan investasi jangka panjang.

15 Fasilitas penanaman modal hanya diberikan kepada penanaman modal yang sekurang-kurangnya memenuhi salah satu kriteria yang terdapat dalam Pasal 18 ayat (3) UUPM. 
dinyatakan selain fasilitas sebagaimana dimaksud dalam Pasal 18 UUPM, Pemerintah memberikan kemudahan pelayanan dan/atau perizinan kepada perusahaan penanaman modal untuk memperoleh:

a. hak atas tanah;

b. fasilitas pelayanan keimigrasian; dan

c. fasilitas perizinan impor.

Selain itu kemudahan pelayanan dan/atau perizinan bagi Hak atas tanah dipertegas kembali dalam Pasal 22 Ayat (1) UUPM yang berbunyi sebagai berikut:

(1) Kemudahan pelayanan dan/atau perizinan hak atas tanah sebagaimana dimaksud dalam Pasal 21 huruf a dapat diberikan dan diperpanjang di muka sekaligus dan dapat diperbaharui kembali atas permohonan penanam modal, berupa:

(a) Hak Guna Usaha dapat diberikan dengan jumlah 95 (sembilan puluh lima) tahun dengan cara dapat diberikan dan diperpanjang di muka sekaligus selama 60 (enam puluh) tahun dan dapat diperbarui selama 35 (tiga puluh lima) tahun;

(b) Hak Guna Bangunan dapat diberikan dengan jumlah 80 tahun dengan cara dapat diberikan dan diperpanjang di muka sekaligus selama 50 (lima puluh) tahun dan dapat diperbarui selama 30 (tiga puluh) tahun; dan

(c) Hak Pakai dapat diberikan dengan jumlah 70 (tujuh puluh) tahun dengan cara dapat diberikan dan diperpanjang di muka sekaligus selama 45 (empat puluh lima) tahun dan dpat diperbarui selama 25 (dua puluh lima) tahun.

Apabila pasal tersebut dibandingkan dengan UUPA maka akan didapat hal-hal sebagai berikut:

a. Pemberian HGU selama 95 tahun menggunakan hitungan UUPA, yaitu pemberian pertama kali 35 tahun, perpanjangan jangka waktu 25 tahun, dengan pembaharuan haknya selama 35 tahun, apabila diakumulasikan seluruhnya berjumlah 95 tahun; 
b. Pemberian HGB untuk pertama kali 30 tahun, perpanjangan jangka waktunya 20 tahun, dan pembaharuan haknya 30 tahun, apabila diakumulasikan seluruhnya berjumlah 80 tahun;

c. Pembaharuan HP untuk pertama kali 25 tahun, perpanjangan jangka waktunya 20 tahun, dan pembaharuan haknya 25 tahun, apabila diakumulasikan seluruhnya berjumlah 70 tahun.

Berdasarkan perbandingan diatas dapat dilihat bahwa UUPM tidak mengubah lembaganya, dan juga tidak mengubah pembatasan jangka waktu pemberiannya, sebagaimana yang disediakan dan ditetapkan perhitungannya dalam UUPA. Perbedaan yang terdapat dalam UUPA dengan UUPM adalah apabila dalam UUPA pemberian perpanjangan jangka waktunya dan pembaharuan haknya dilakukan secara bertahap sedangkan UUPM memberikan hal tersebut secara sekaligus. Jangka waktu yang panjang tersebut dapat dikatakan masuk di akal karena dalam beberapa kegiatan penanaman modal membutuhkan jangka waktu yang cukup lama untuk mendapatkan keuntungannya.

Persyaratan bagi kegiatan penanaman modal yang dapat diberikan dan diperpanjang di muka sekaligus yang terdapat dalam Pasal 22 ayat (2) UUPM antara lain:

a. Penanaman modal yang dilakukan dalam jangka panjang dan terkait dengan perubahan struktur perekonomian Indonesia yang lebih berdaya saing;

b. Penanaman modal dengan tingkat risiko penanaman modal yang memerlukan jangka pengembalian modal dalam jangka panjang sesuai dengan jenis kegiatan penanaman modal yang dilakukan;

c. Penanaman modal yang tidak memerlukan area yang luas:

(yang dimaksud dengan "area yang luas" adalah luas tanah yang diperlukan untuk kegiatan penananman modal dengan mempertimbangkan kepadatan penduduk, bidang usaha, atau jenis usaha yang ditentukan dengan peraturan perundang-undangan)

d. Penanaman modal dengan hak atas tanah negara; dan

e. Penanaman modal tidak mengganggu rasa keadilan masyarakat dan tidak merugikan kepentingan umum.

Berdasarkan Pasal 22 ayat (3) UUPM, hak atas tanah yang telah disebutkan diatas baru dapat diperbaharui apabila setelah dilakukan evaluasi, 
tanah tersebut masih digunakan dan diusahakan dengan baik sesuai dengan keadaan, sifat, dan tujuan pemberian hak. Menurut Pasal 22 ayat (4) UUPM bahwa pemberian dan perpanjangan hak atas tanah yang diberikan sekaligus di muka dan dapat diperbaharui tersebut dapat dihentikan atau dibatalkan oleh Pemerintah jika perusahaan penanaman modal menelantarkan tanah, merugikan kepentingan umum, menggunakan atau menfaatkan tidak sesuai dengan maksud dan tujuan pemberian hak atas tanahnya, serta melanggar ketentuan peraturan perundang-undangan di bidang pertanahan.

\section{Perubahan Pasal Mengenai Kebijakan Pertanahan oleh Mahkamah Konstitusi}

Uji materi terhadap enam pasal UU Penanaman Modal diajukan oleh sejumlah lembaga swadaya masyarakat, antara lain Perhimpunan Bantuan Hukum dan Hak Asasi Manusia Indonesia (PBHI), Wahana Lingkungan Hidup (Walhi), serta 22 pemohon perseorangan yang terdiri atas buruh, petani, dan pedagang tradisional yang diwakili kuasa hukum dari Yayasan Lembaga Bantuan Hukum Indonesia (YLBHI). ${ }^{16}$

Salah satu hal yang menjadi perhatian dalam sidang uji materi tersebut adalah mengenai kebijakan pertanahan dalam UUPM yang terdapat dalam Pasal 22 ayat (1) sampai dengan ayat (5). Pada akhirnya Mahkamah Konsitusi (MK) menyatakan bahwa sebagian ketentuan Pasal 22 UUPM bertentangan dengan konstitusi yang mana hal tersebut disampaikan dalam sidang pengucapan putusan perkara 21-22/PUU-V/2007, Selasa $(25 / 3)$, di Ruang Sidang MK. ${ }^{17}$

Bagian dari Pasal 22 UUPM yang bertentangan dengan UUD 1945, yaitu Pasal 22 ayat (1) sepanjang menyangkut kata-kata "di muka sekaligus" dan "berupa" dan Pasal 22 ayat (2) sepanjang menyangkut kata-kata "di muka sekaligus" dan Pasal 22 ayat (4) sepanjang menyangkut kata-kata "sekaligus di muka" juga dinyatakan bertentangan dengan UUD $1945 .{ }^{18}$

${ }^{16}$ Tri Wibowo Santoso, "UU Penanaman Modal Asing Abaikan Rakyat Miskin", $<$ http://www.vhrmedia.com/vhr-newsberita,UU-Penanaman-Modal-Abaikan-Rakyat-Miskin947.html>, diakses tanggal 6 November 2007.

17 Luthfi Widagdo Eddyono, "Sebagian Ketentuan UU Penanaman Modal Bertentangan Dengan UU Konstitusi", <http://www.mahkamahkonstitusi.go.id/berita.php? newscode $=606>$, diakses tanggal, 25 Maret 2008 .

${ }^{18}$ Ibid. 
Banyak ahli yang memberikan keterangan dalam sidang uji materil ini baik dari pihak pemohon maupun dari Pemerintah. Salah satunya untuk ahli dari bidang Agraria diwakili oleh Kurnia Toha, S.H., LL.M.,. ${ }^{19}$ Pada kesempatannya untuk memberikan keterangan telah dikemukakan bahwa perhitungan jangka waktu pemberian Hak atas Tanah yang terdapat dalam UUPM tidak berbeda dengan yang terdapat dalam UUPA. ${ }^{20}$ Namun Mahkamah Konstitusi tetap berpendapat bahwa uji materiil dari UndangUndang Penanaman Modal ini adalah terhadap Undang-Undang Dasar 1945 bukan terhadap Undang-Undang lainnya. ${ }^{21}$ Selain itu Mahkamah Konstitusi membatalkan Pasal 22 tersebut dengan pertimbangan sebagai berikut: ${ }^{22}$

1. Kewenangan negara dalam pencabutan atau pembatalan hak atas tanah dalam kegiatan penanaman modal sangat terbatas karena alasan pencabutan atau pembatalan hak atas tanah ditentukan secara limitatif dalam Pasal 22 ayat 4 sehingga negara tidak lagi bebas menjalankan kehendaknya untuk menghentikan atau tidak memperpanjang hak-hak atas tanah jika diberikan perpanjangan Hak atas Tanah diberikan di muka sekaligus;

2. Apabila Negara, c.q. Pemerintah, menghentikan atau membatalkan hak-hak atas tanah (HGU, HGB, dan HP) yang dapat diperpanjang di muka sekaligus itu di mana kemudian tindakan itu dipersoalkan secara hukum oleh pihak penanam modal maka berarti telah terjadi sengketa penanaman modal antara Pemerintah dan penanam modal. Untuk perusahaan penanam modal dalam negeri akan ditempuh jalan arbitrase yang apabila tidak disepakati akan ditempuh penyelesaian melalui Pengadilan sedangkan untuk perusahaan penanam modal asing akan ditempuh jalan arbitrase internasional. Menurut pendapat Mahkamah Konstitusi, hal tersebut melemahkan kedaulatan rakyat di bidang ekonomi karena arbitrase adalah sarana penyelesaian sengketa antarpihak-pihak yang sederajat berarti, dengan kata lain, tindakan negara tersebut oleh Pasal 32 Ayat (4) UU Penanaman

${ }^{19}$ Lihat Putusan Mahkamah Konstitusi Nomor 21-22/PUU-V/2007, hal. 209.

${ }^{20}$ Lihat Risalah Sidang Perkara Nomor 21/PUU-V/2007 dan Perkara Nomor 22/PUU-V/2007 Perihal Pengujian Undang-Undang Republik Indonesia Nomor 25 Tahun 2007 Tentang Penanaman Modal Terhadap Undang-Undang Dasar 1945 Acara Mendengar Keterangan Ahli Dari Pemohon Dan Pemerintah, hal. 99-100.

${ }^{21}$ Lihat Putusan Mahkamah Konstitusi Nomor 21-22/PUU-V/2007, hal. 257.

${ }^{22}$ Lihat Putusan Nomor 21-22/PUU-V/2007, hal. 257-262. 
Modal secara implisit dikualifikasikan sebagai tindakan subjek hukum perdata biasa (de jure gestiones) yang kedudukannya sederajat dengan penanam modal. Seharusnya klausul penyelesaian sengketa melalui arbitrase dicantumkan dalam rumusan kontrak, kasus demi kasus, bukan dalam perumusan undang-undang yang berlaku umum dan bersifat permanen yang justru mempersulit Pemerintah sendiri dan juga mencerminkan ketidakpercayaan terhadap institusi peradilan di Indonesia yang dilegalisasikan secara permanen oleh pembentuk undang-undang;

3. Pemberian dan perpanjangan hak-hak atas tanah yang diberikan sekaligus di muka tersebut juga menghambat negara untuk melakukan pemerataan kesempatan dalam memperoleh hak-hak atas tanah secara adil yang mana alasan tersebut di atas tidak termasuk salah satu alasan yang dapat digunakan oleh negara untuk menghentikan atau membatalkan hak-hak atas tanah sebagaimana disebutkan dalam Pasal 22 ayat (4). Dengan demikian, sebagian dari kewenangan negara untuk melakukan tindakan pengelolaan (beheersdaad), dalam hal ini kewenangan untuk melakukan pemerataan kesempatan untuk mendapatkan hak-hak atas tanah secara lebih adil dan lebih merata, menjadi terhalang.

Berdasarkan pertimbangan-pertimbangan tersebut maka Pasal 22 dinyatakan bertentangan dengan Undang-Undang Dasar 1945 khususnya pasal 33 ayat $(3)^{23}$ dan tidak mempunyai kekuatan hukum mengikat. ${ }^{24}$ Sehingga bunyi Pasal 22 diubah menjadi sebagai berikut: ${ }^{25}$

\section{Pasal 22}

(1) Kemudahan pelayanan dan/atau perizinan hak atas tanah sebagaimana dimaksud dalam Pasal 21 huruf a dapat diberikan dan diperpanjang dan dapat diperbarui kembali atas permohonan penanam modal.

${ }^{23}$ Pasal 33 ayat (3) berbunyi sebagai berikut.

"Bumi dan air dan kekayaan alam yang terkandung di dalamnya dikuasai oleh negara dan dipergunakan untuk sebesar-besar kemakmuran rakyat".

${ }^{24}$ Luthfi Widagdo Eddyono, Loc. Cit.

${ }^{25}$ Ibid. 
(2) Hak atas tanah sebagaimana dimaksud pada Ayat (1) dapat diberikan dan diperpanjang untuk kegiatan penanaman modal, dengan persyaratan antara lain:

(a) penanaman modal yang dilakukan dalam jangka panjang dan terkait dengan perubahan struktur perekonomian Indonesia yang lebih berdaya saing;

(b) penanaman modal dengan tingkat risiko penanaman modal yang memerlukan pengembalian modal dalam jangka panjang sesuai dengan jenis kegiatan penanaman modal yang dilakukan;

(c) penanaman modal yang tidak memerlukan area yang luas;

(d) penanaman modal dengan menggunakan hak atas tanah negara; dan

(e) penanaman modal yang tidak mengganggu rasa keadilan masyarakat dan tidak merugikan kepentingan umum.

(3) Hak atas tanah dapat diperbarui setelah dilakukan evaluasi bahwa tanahnya masih digunakan dan diusahakan dengan baik sesuai dengan keadaan, sifat, dan tujuan pemberian hak.

(4) Pemberian dan perpanjangan hak atas tanah yang diberikan dan yang dapat diperbarui sebagaimana dimaksud pada Ayat (1) dan Ayat (2) dapat dihentikan atau dibatalkan oleh Pemerintah jika perusahaan penanaman modal menelantarkan tanah, merugikan kepentingan umum, menggunakan atau memanfaatkan tanah tidak sesuai dengan maksud dan tujuan pemberian hak atas tanahnya, serta melanggar ketentuan peraturan perundang-undangan di bidang pertanahan. 
Usai sidang Wakil Kepala Badan Koordinasi Penanaman Modal (BKPM) Yu'san mengatakan bahwa pasal 22 ayat 1 dan 2 ini akan diganti bahasanya dengan menggunakan acuan yang ada pada UU Agraria. ${ }^{26}$ Dapat dilihat bahwa kebijakan pertanahan yang terdapat dalam UUPM kembali kepada UUPA walaupun pada dasarnya sedari awal kebijakan pertanahan dalam UUPM tidak bertentangan dengan UUPA.

Apabila kita tarik pendapat bahwa ketentuan dalam UU Penanaman Modal yang tidak jauh berbeda/sama dengan UUPA namun dikatakan telah melanggar Undang-Undang Dasar 1945 maka kita dapat mengatakan bahwa UUPA pun sebenarnya bertentangan dengan UUD 1945 padahal telah diketahui dan diakui bahwa UUPA merupakan pengejewantahan nilai dari Pasal 33 UUD 1945. Dapat dilihat pula bahwa ketentuan perundangundangan yang terdapat dalam UUPA harus diubah dalam rangka mengikuti perkembangan zaman. Apabila semua undang-undang yang berkaitan dengan UUPM harus diubah maka UUPA pun merupakan salah satu undang-undang yang harus dirubah. ${ }^{27}$

\section{Kesimpulan}

1. Pada dasarnya UUPM tidak mengubah baik lembaga, jangka waktu maupun pembatasan jangka waktu pemberian tanah sebagaimana yang terdapat dalam UUPA. Perbedaan yang terdapat antara UUPA dengan UUPM hanyalah pada UUPA pemberian perpanjangan jangka waktunya dilakukan secara bertahap sedangkan dalam UUPM diberikan secara sekaligus.

2. Pemberian Hak atas Tanah beserta jangka waktu yang dapat diperpanjang sekaligus di muka bukanlah hal yang baru dan telah diatur dalam UUPA namun Mahkamah Konstitusi berpendapat hal tersebut dapat melemahkan kehendak bebas negara, bertentangan dengan demokrasi ekonomi kerakyatan dan menghambat negara untuk melakukan pemerataan kesempatan bagi pihak lain yang membutuhkan untuk memiliki tanah.

26 Wahyu Daniel, "MK Ganti I Pasal UU Penanaman Modal". $<$ www.detikfinance.com/read/2008/03/25/144707/913025/4/mk-ganti-1-pasal-uu-penanamanmodal>. diakses tanggal 25 Maret 2008.

${ }^{27}$ Lihat Pasal 36 UUPM, "Semua ketentuan peraturan perundang-undangan yang berkaitan secara langsung dengan penanaman modal wajib mendasarkan dan menyesuaikan pengaturannya pada Undang-Undang ini." 
3. Berdasarkan bunyi Pasal 22 UUPM dan keterangan dari Ketua BKPM maka kebijakan pertanahan untuk penanaman modal kembali kepada UUPA. 


\section{Daftar Pustaka}

Harsono, Boedi. Hukum Agraria Indonesia: Himpunan Peraturan-Peraturan Hukum Tanah, Jakarta: Djambatan: 2002.

. Hukum Agraria Indonesia Sejarah Pembentukan UndangUndang Pokok Agraria, Isi dan Pelaksanaanya, Jakarta: Djambatan, 2003.

Hutagalung, Arie S. Tebaran Pemikiran Seputar Masalah Hukum Tanah, Jakarta: Lembaga Pemberdayaan Hukum Indonesia, 2005.

. dan Markus Gunawan. Kewenangan Pemerintah Di Bidang Pertanahan, Jakarta: RajaGrafindo Persada. 2008.

Indonesia. Undang-Undang Dasar 1945.

. Undang-Undang No. 5 Tahun 1960 Tentang Peraturan Dasar Pokok-Pokok Agraria, LN-1960-104, TLN No. 2403.

. Undang-Undang No. 25 Tahun 2007 Tentang Penanaman Modal, LN No. 67, TLN No. 4724.

. Peraturan Pemerintah No. 40 Tahun 1996 Tentang Hak Guna Usaha, Hak Guna Bangunan Dan Hak Pakai Atas Tanah, LN. 1196-58, TLN No. 3643.

Mahkamah Konstitusi, Putusan No. 21-22/PU-V/2008 Tentang Uji Materil Undang-Undang Penanaman Modal. Jakarta: Selasa, 25 Maret 2008.

Risalah Sidang Perkara Nomor 21/PUU-V/2007 dan Perkara Nomor 22/PUU-V/2007 Perihal Pengujian Undang-Undang Republik Indonesia Nomor 25 Tahun 2007 Tentang Penanaman Modal Terhadap Undang-Undang Dasar 1945 dengan Acara Mendengar Keterangan Ahli Dari Pemohon Dan Pemerintah (IV). Jakarta: Selasa 30 November 2007.

. Risalah Sidang Perkara Nomor 21/PUU-V/2007 dan Perkara Nomor 22/PUU-V/2007 Perihal Perihal Pengujian Undang-Undang Republik Indonesia Nomor 25 Tahun 2007 Tentang Penanaman Modal Terhadap Undang-Undang Dasar 1945 dengan Acara Mendengar Keterangan Ahli Dari Pemohon Dan Pemerintah (V). Jakarta: Rabu, 5 Desember 2007.

(CRP/Ycb), "Judicial Review: UUPM vs. Tanah Untuk Rakyat", $<$ http://www.hukumonline.com/ detail.asp?id=17301\&cl=Berita>, diakses tanggal 3 Agustus 2007. 
Santoso, Tri Wibowo. "UU Penanaman Modal Asing Abaikan Rakyat Miskin", <http://www.vhrmedia.com/vhr-news/berita,UU-PenanamanModal-Abaikan-Rakyat-Miskin-947.html>, diakses tanggal 6 November 2007.

Eddyono, Luthfi Widagdo. "Sebagian Ketentuan UU Penanaman Modal Bertentangan Dengan UU Konstitusi", <http://www.mahkamah konstitusi.go.id/berita.php?newscode $=606>$, diakses tanggal 25 Maret 2008.

Daniel, Wahyu. "MK Ganti I Pasal UU Penanaman Modal", $<$ www.detikfinance.com/read/2008/03/25/144707/913025/4/mk-ganti1-pasal-uu-penanaman-modal>, diakses tanggal 25 Maret 2008. 